\title{
Tenacibaculum litoreum sp. nov., isolated from tidal flat sediment
}

Correspondence

Byung Cheol Cho bccho@snu.ac.kr

\author{
Dong Han Choi, ${ }^{1}$ Yoon-Gon Kim, ${ }^{1}$ Chung Yeon Hwang, ${ }^{1}$ Hana $\mathrm{Yi}^{2}{ }^{2}$ \\ Jongsik Chun ${ }^{2}$ and Byung Cheol $\mathrm{Cho}^{1}$
}

School of Earth and Environmental Sciences and Research Institute of Oceanography and School of Biological Sciences², Seoul National University, San 56-1 Shillim-dong, Kwanak-gu, Seoul 151-742, Republic of Korea
Since the genus Tenacibaculum was proposed by Suzuki et al. (2001), six species have been isolated from various marine sources. Two species, Tenacibaculum maritimum and Tenacibaculum ovolyticum, were reclassified from the former [Flexibacter] maritimus isolated from diseased red sea bream fingerling (Wakabayasahi et al., 1986) and [Flexibacter] ovolyticus isolated from halibut egg (Hansen et al., 1992). Two other species, Tenacibaculum mesophilum and Tenacibaculum amylolyticum, were isolated from homogenates of sponge and surfaces of marine macroalgae, respectively (Suzuki et al., 2001). Tenacibaculum skagerrakense and Tenacibaculum lutimaris were recently isolated from sea water (Frette et al., 2004) and tidal flat sediment (Yoon et al., 2005), respectively.

In this study, strain $\mathrm{CL}-\mathrm{TF} 13^{\mathrm{T}}$, related to the genus Tenacibaculum, was isolated from tidal flat sediment in Ganghwa, Korea. The sediment slurry was spread onto a plate containing marine agar 2216 (MA; Difco) and the plate was incubated at $30^{\circ} \mathrm{C}$ for 1 week. Strain CL-TF $13^{\mathrm{T}}$ was isolated on the plate and subsequently purified four times on MA at

Published online ahead of print on 4 November 2005 as DOI 10.1099/ ijs.0.64044-0.

Abbreviations: ASW, artificial sea water; ECL, equivalent chain-length. The GenBank/EMBL/DDBJ accession number for the 16S rRNA gene sequence of strain CL-TF13 ${ }^{\top}$ is AY962294.
$30{ }^{\circ} \mathrm{C}$. The strain was maintained both on $\mathrm{MA}$ at $4{ }^{\circ} \mathrm{C}$ and in marine broth 2216 (MB; Difco) supplemented with $30 \%$ (v/v) glycerol at $-80^{\circ} \mathrm{C}$.

The 16S rRNA gene was amplified from a single colony by PCR with Taq DNA polymerase (Bioneer) and primers $27 \mathrm{~F}$ and 1492R (Lane, 1991). The PCR product was purified using the AccuPrep PCR Purification kit (Bioneer) and cloned using the pCR2.1 TOPO TA Cloning kit (Invitrogen). Sequencing of the 16S rRNA gene was performed with an Applied Biosystems automatic sequencer (ABI 3730XL) at Macrogen (Seoul, Korea). The almost-complete $16 \mathrm{~S}$ rRNA gene sequence of strain CL-TF $13^{\mathrm{T}}$ (1446 bp) was obtained and compared with $16 \mathrm{~S}$ rRNA gene sequences available in GenBank using BLASTN (Altschul et al., 1990) searches. The sequence of strain CL-TF $13^{\mathrm{T}}$ was manually aligned with those of the type strains of six Tenacibaculum species and with the type species of other genera in the family Flavobacteriaceae obtained from GenBank and Ribosomal Database Project (Cole et al., 2003) databases using known 16S rRNA secondary structure information. Phylogenetic trees were obtained by neighbour-joining (Saitou \&Nei, 1987), maximum-parsimony (Fitch, 1971) and maximum-likelihood (Felsenstein, 1981) methods. An evolutionary distance matrix for the neighbour-joining method was generated according to the model of Jukes \& Cantor (1969). The robustness of tree topologies was assessed by bootstrap analyses based on 1000 
replications for neighbour-joining and maximum-parsimony methods and 100 replications for the maximum-likelihood method. Alignment analysis was carried out using the jPHYDIT program (version 1.0; http://chunlab.snu.ac.kr/ jphydit/) and phylogenetic analysis was carried out using MEGA3 (Kumar et al., 2004) and PAUP 4.0 (Swofford, 1998). Likelihood parameters were estimated by the hierarchical ratio tests in MODELTEST, version 3.04 (Posada \& Crandall, 1998). Sequence similarity indicated that the closest relatives of strain CL-TF13 ${ }^{\mathrm{T}}$ were T. lutimaris $(97 \cdot 4 \%)$, T. mesophilum (97.1\%), T. skagerrakense $(96 \cdot 5 \%)$, T. amylolyticum $(96 \cdot 0 \%)$, T. ovolyticum $(95 \cdot 4 \%)$ and T. maritimum $(94 \cdot 2 \%)$. Phylogenetic analyses based on the 16S rRNA gene sequence showed that strain CL-TF $13^{\mathrm{T}}$ formed a robust cluster with species of the genus Tenacibaculum (Fig. 1). Thus, it is clear that our isolate belongs to the genus Tenacibaculum. The DNA G + C content was determined using the thermal denaturation method (Mandel \& Marmur, 1968) and was found to be $30 \mathrm{~mol} \%$, at the lower limit of the range reported in other Tenacibaculum species (Table 1). As the similarities between strain CL-TF $13^{\mathrm{T}}$ and two species (T. lutimaris and $T$. mesophilum) were close to the theoretical threshold (97\%) for the delineation of bacterial species based on 16S rRNA gene sequence similarity (Stackebrandt \& Goebel, 1994), the relatedness of genomic DNA was determined by dot-blot hybridization. Probe DNA labelling was performed using a nick translation kit (Roche) and hybridization and detection were done using the DIG labelling and detection kit (Roche) according to the manufacturer's instruction. The DNA-DNA relatedness between CL-TF $13^{\mathrm{T}}$ and T. lutimaris was $11 \%$, while that for T. mesophilum was $46 \%$. These values are below the currently accepted limit of DNA relatedness (70\%) for the phylogenetic definition of a species (Stackebrandt \& Goebel, 1994) and therefore provide evidence that the isolate represents a novel species in the genus Tenacibaculum.
Morphological and physiological analyses were performed. Gram staining was performed as described by Smibert \& Krieg (1994). Cell morphology was examined by phasecontrast microscopy and transmission electron microscopy (JEOL EX2) with cells grown at $30^{\circ} \mathrm{C}$ in MB. Gliding motility was observed by the hanging-drop method (Suzuki et al., 2001). Anaerobic growth was checked on MA using the GasPak anaerobic system (BBL). Catalase and oxidase activities were determined according to the protocols described by Smibert \& Krieg (1994), and gelatinase, amylase, DNase and nitrate reductase activities and degradation of Tween 80 were examined as described by Hansen \& Sørheim (1991). Cells are rod-shaped (Fig. 2) and motile by means of gliding. Spherical cells were rarely observed in ageing cultures of CL-TF $13^{\mathrm{T}}$ (Fig. 2b). Colony size, shape and colour were determined on MA after 5 days incubation at $30^{\circ} \mathrm{C}$. Colonies were pale yellow in colour, greenish glistening and irregular with spreading edges on MA. Colonies were $5-10 \mathrm{~mm}$ in diameter and not adherent to the agar. Other morphological characteristics are shown in Table 1.

The temperature range for growth was determined on the basis of colony formation on MA plates that were incubated at $5-45^{\circ} \mathrm{C}$. The $\mathrm{pH}$ range (5-11) for growth was determined by changes in $\mathrm{OD}_{600}$ with time in $\mathrm{MB}$. The final $\mathrm{pH}$ was adjusted using $\mathrm{NaOH}$ and $\mathrm{HCl}$ solutions. Tolerance of CL$\mathrm{TF} 13^{\mathrm{T}}$ to $\mathrm{NaCl}$ and sea salts (Sigma) was determined using the synthetic ZoBell broth $(5 \mathrm{~g}$ Bacto peptone, $1 \mathrm{~g}$ yeast extract, $0 \cdot 1 \mathrm{~g}$ ferric citrate, 11 distilled water) with various concentrations $[0,1,3,5,7,10,15,20,25 \%(\mathrm{w} / \mathrm{v})]$ of $\mathrm{NaCl}$ or sea salts. Nitrate reduction, production of indole, arginine dihydrolase, urease, gelatinase and $\beta$-galactosidase, acid production from glucose and hydrolysis of aesculin were tested using API 20NE kit (bioMérieux) according to the

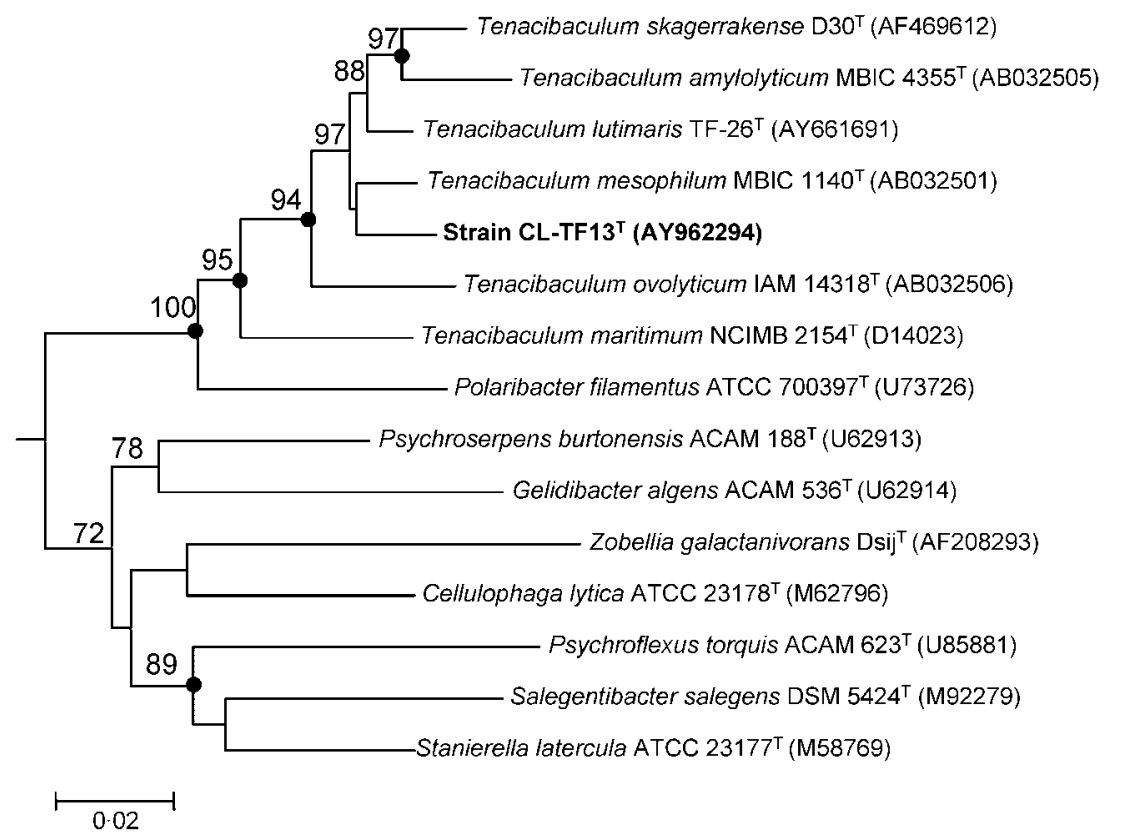

Fig. 1. Neighbour-joining tree based on rRNA gene sequences showing relationships between strain $\mathrm{CL}_{-} \mathrm{TF} 13^{\top}$, members of the genus Tenacibaculum and other related genera belonging to the family Flavobacteriaceae. Only bootstrap values above $70 \%$ are shown (1000 resamplings) at the branching points. Solid circles indicate that the corresponding nodes are also recovered in maximum-likelihood and maximum-parsimony trees. Flexibacter flexilis ATCC $23079^{\top}$ (M62794) was used as an outgroup (not shown). Bar, 0.02 nt substitution per site. 
Table 1. Differential phenotypic characteristics of strain CL-TF13 ${ }^{\top}$ and other Tenacibaculum species

Strains: 1, T. litoreum sp. nov. CL-TF13 ${ }^{\mathrm{T}} ; 2$, T. lutimaris TF-26 ${ }^{\mathrm{T}} ; 3$, T. skagerrakense $\mathrm{D} 30^{\mathrm{T}} ; 4$, T. amylolyticum MBIC $4355^{\mathrm{T}}$; 5, T. mesophilum MBIC $1140^{\mathrm{T}}$; 6, T. ovolyticum IAM $14318^{\mathrm{T}}$; 7, T. maritimum NCIMB 2154 ${ }^{\mathrm{T}}$. Data from Yoon et al. (2005), Frette et al. (2004), Suzuki et al. (2001) or this study. +, Positive; -, negative; W, weakly positive; opt., optimal; NA, not available; NG, no growth with NaCl only. All species are Gram-negative, rod-shaped and positive for catalase and oxidase. Data for API ZYM were obtained in this study.

\begin{tabular}{|c|c|c|c|c|c|c|c|}
\hline Characteristic & 1 & 2 & 3 & 4 & 5 & 6 & 7 \\
\hline Origin & Tidal flat & Tidal flat & Pelagic & Macroalgae & $\begin{array}{c}\text { Sponge, } \\
\text { macroalgae }\end{array}$ & Halibut egg & $\begin{array}{c}\text { Diseased red } \\
\text { sea bream } \\
\text { fingerling }\end{array}$ \\
\hline \multicolumn{8}{|l|}{ Colony morphology:* } \\
\hline Shape & $\begin{array}{l}\text { Irregular, } \\
\text { spreading } \\
\text { edge }\end{array}$ & $\begin{array}{l}\text { Irregular, } \\
\text { spreading } \\
\text { edge }\end{array}$ & $\begin{array}{l}\text { Circular, } \\
\text { convex, } \\
\text { spreading } \\
\text { edge }\end{array}$ & $\begin{array}{l}\text { Circular, } \\
\text { spreading } \\
\text { edge }\end{array}$ & $\begin{array}{l}\text { Irregular, } \\
\text { spreading } \\
\text { edge }\end{array}$ & $\begin{array}{l}\text { Regular } \\
\text { edge }\end{array}$ & $\begin{array}{l}\text { Uneven } \\
\text { edge }\end{array}$ \\
\hline Diameter at 5 days $(\mathrm{mm})$ & $5-10$ & $10-20$ & $5-20$ & $23-27$ & $30-60$ & NA & $<5$ \\
\hline Colour & Pale yellow & Pale yellow & Bright yellow & Yellow & Yellow & Pale yellow & Pale yellow \\
\hline Cell size $(\mu \mathrm{m})$ & $0 \cdot 3-0 \cdot 5 \times 2-35$ & $0 \cdot 5 \times 2-10$ & $0 \cdot 5 \times 2-15$ & $0 \cdot 4 \times 2-5$ & $0 \cdot 5 \times 1 \cdot 5-10$ & $0 \cdot 5 \times 2-20$ & $0 \cdot 5 \times 2-30$ \\
\hline Spherical cells & Very rare & Very rare & Frequent & Very rare & Very rare & $\begin{array}{c}\text { Not } \\
\text { observed } \dagger\end{array}$ & Frequent $\dagger$ \\
\hline Sea water & $25-250$ 丰 & $25-175 \ddagger \varsigma$ & $25-150 \ddagger$ & $50-100$ & $10-100$ & $70-100$ & $30-100$ \\
\hline Temperature range $\left({ }^{\circ} \mathrm{C}\right)$ & $5-40$ & $10-39$ & $10-40$ & $20-35$ & $15-40$ & $4-25$ & $15-34$ \\
\hline Optimal temperature $\left({ }^{\circ} \mathrm{C}\right)$ & $35-40$ & $30-37$ & $25-37$ & $27-30$ & $28-35$ & $\mathrm{ND}$ & 30 \\
\hline $\mathrm{pH}$ range & $6-10$ & 7-8 (opt.) & $6-9$ & $5 \cdot 3-8 \cdot 3$ & $5 \cdot 3-9$ & $5 \cdot 9-8 \cdot 6$ & $5 \cdot 9-8 \cdot 6$ \\
\hline Growth at $\mathrm{pH} 5$ & - & + & - & - & - & - & - \\
\hline DNA G $+\mathrm{C}$ content $(\mathrm{mol} \%)$ & 30 & $32 \cdot 3-32 \cdot 8$ & $35 \cdot 2$ & $30 \cdot 9$ & $31 \cdot 6-32 \cdot 0$ & $30 \cdot 3-32 \cdot 0$ & $31 \cdot 3-32 \cdot 5$ \\
\hline Nitrate reduction & + & - & + & $\mathrm{W}$ & - & + & + \\
\hline \multicolumn{8}{|l|}{ Degradation of: } \\
\hline Starch & + & - & + & + & - & - & - \\
\hline Gelatin & + & + & NA & + & + & + & + \\
\hline \multicolumn{8}{|l|}{ API ZYM: } \\
\hline Citrate & - & NA & + & - & - & - & - \\
\hline L-Leucine & - & - & $\mathrm{W}$ & - & - & - & - \\
\hline Sucrose & - & - & + & - & - & - & - \\
\hline L-Proline & + & - & + & + & + & - & - \\
\hline L-Glutamate & - & - & + & + & + & - & W \\
\hline DL-Aspartate & - & - & + & - & + & - & - \\
\hline D-Glucose & - & - & + & NA & NA & $\mathrm{NA}$ & NA \\
\hline D-Mannose & - & NA & + & NA & NA & NA & NA \\
\hline
\end{tabular}

${ }^{\star}$ For analyses of colony morphology, CL-TF $13^{\mathrm{T}}$ and T. lutimaris were grown on MA at $30^{\circ} \mathrm{C}$, T. skagerrakense was grown on ZoBell plate at $20^{\circ} \mathrm{C}$. The other strains were grown on $1 / 5 \mathrm{LBM}$ agar (Suzuki et al., 2001) at $20^{\circ} \mathrm{C}$.

$\dagger$ J.-F. Bernardet, personal communication.

$\ddagger$ Percentage of sea-water strength was calculated using a relation of $100 \%$ sea water $=40 \mathrm{~g}$ sea salts $1^{-1}$ (Frette et al., 2004).

$\S$ Data from this study. 


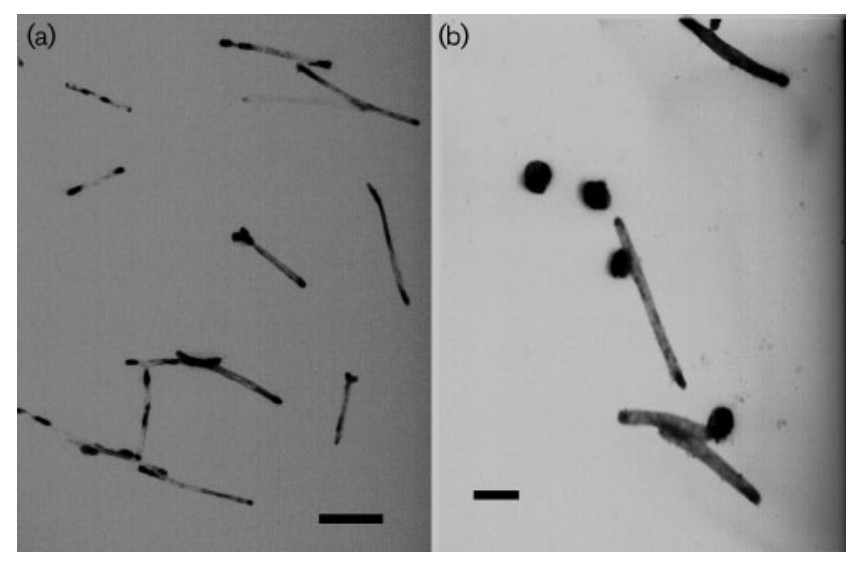

Fig. 2. Transmission electron micrograph of negatively stained cells of strain CL-TF13 ${ }^{\top}$. Bars, $2 \mu \mathrm{m}$ (a) and $1 \mu \mathrm{m}$ (b).

manufacturer's instruction, except that the cell suspension was prepared using artificial sea water (ASW; $24 \mathrm{~g} \mathrm{NaCl}$, $5 \cdot 1 \mathrm{~g} \mathrm{MgCl}_{2}, 4 \mathrm{~g} \mathrm{Na}_{2} \mathrm{SO}_{4}, 1 \cdot 1 \mathrm{~g} \mathrm{CaCl}_{2}, 0 \cdot 7 \mathrm{~g} \mathrm{KCl}, 0 \cdot 2 \mathrm{~g}$ $\mathrm{NaHCO}_{3}, 0.1 \mathrm{~g} \mathrm{KBr}, 0.027 \mathrm{~g} \mathrm{H}_{3} \mathrm{BO}_{3}, 0.024 \mathrm{~g} \mathrm{SrCl}_{2}, 0.003 \mathrm{~g}$ NaF, 11 distilled water; Lyman \& Fleming, 1940) as a suspension medium. Other enzyme activities were also assayed by using the API ZYM kit (bioMérieux) and ASW as a suspension medium. Carbon utilization was tested on basal medium agar $\left(0.2 \mathrm{~g} \mathrm{NH}_{4} \mathrm{Cl}, 0.2 \mathrm{~g} \mathrm{NaNO}_{3}, 0.05 \mathrm{~g}\right.$ yeast extract, $15 \mathrm{~g}$ Bacto agar, $11 \mathrm{ASW}$ ) containing $0.4 \%$ of the carbon source. Incubation was prolonged for 1 month and growth was scored as negative when growth was equal to or less than that in the negative control, without any carbon source. For the analyses of API 20NE, API ZYM and carbon utilization tests, T. lutimaris $\mathrm{TF}-26^{\mathrm{T}}$ and T. maritimum NCIMB $2514^{\mathrm{T}}$ were employed as reference strains. In contrast to the other Tenacibaculum species, CL-TF13 ${ }^{\mathrm{T}}$ grew optimally at $35-40^{\circ} \mathrm{C}$ and was able to grow at $\mathrm{pH} 10$, with $3-5 \%(\mathrm{w} / \mathrm{v}) \mathrm{NaCl}$ and with $1-10 \%(\mathrm{w} / \mathrm{v})$ sea salts (Table 1). The strain showed positive responses in tests for nitrate reductase, gelatinase, DNase, amylase, catalase, cytochrome oxidase and degradation of Tween 80 (Table 1). The other results of biochemical and physiological tests are given in Table 1 and the species description.

Isoprenoid quinone was isolated according to Minnikin et al. (1984) and analysed by HPLC as described by Collins (1985). The major isoprenoid quinone in CL-TF13 ${ }^{\mathrm{T}}$ was menaquinone-6 (MK-6). Pigments were extracted from cells cultured in the dark for 1 day by using methanol and analysed by HPLC system. Flexirubin pigments were detected by a colour-shift test using $20 \%(\mathrm{w} / \mathrm{v}) \mathrm{KOH}$ solution (Reichenbach, 1992). CL-TF13 ${ }^{\mathrm{T}}$ contained zeaxanthin as the major carotenoid pigment but did not contain flexirubin pigments. Thus, the characteristics of isoprenoid quinone and pigments were the same as other Tenacibaculum species. The fatty acid methyl esters in whole cells, which were grown on $\mathrm{MA}$ at $30^{\circ} \mathrm{C}$ for 1 day, were analysed by gas chromatography according to the instructions of the
Microbial Identification system (MIDI) at the Korean Culture Center of Microorganisms (Seoul, Korea). Similar to other members of the genus, the fatty-acid profile of CL-TF $13^{\mathrm{T}}$ was dominated by summed feature $3\left(\mathrm{C}_{16: 1} \omega 7 \mathrm{c}\right.$ and/or iso- $\mathrm{C}_{15: 0}$ 2-OH, $19 \cdot 6 \%)$, iso- $\mathrm{C}_{15: 0}(18 \cdot 8 \%)$, iso- $\mathrm{C}_{17: 0} 3-\mathrm{OH}(13 \cdot 6 \%)$, iso- $\mathrm{C}_{15: 1}(8 \cdot 2 \%)$, iso- $\mathrm{C}_{16: 0} 3-\mathrm{OH}(6 \cdot 8 \%)$ and iso- $\mathrm{C}_{15: 0} 3-$ $\mathrm{OH}(6 \cdot 6 \%)$ (Table 2). However, the relative proportions of

Table 2. Cellular fatty-acid content of strain CL-TF13 ${ }^{\top}$ and other Tenacibaculum species

Values are percentages of total fatty acids. Strains: 1, T. litoreum sp. nov. CL-TF13 ${ }^{\mathrm{T}} ; 2$, T. lutimaris $\mathrm{TF}-26^{\mathrm{T}} ; 3$, T. skagerrakense $\mathrm{D} 30^{\mathrm{T}} ; 4$, T. mesophilum MBIC $1140^{\mathrm{T}} ; 5$, T. maritimum NCIMB $2154^{\mathrm{T}}$. No fatty acid data are available for T. ovolyticum or $T$. amylolyticum. Data from Yoon et al. (2005) and this study. Fatty acids that represented $<0.5 \%$ in all strains were omitted. ND, Not detected; -, ND or $<0.5 \%$. ECL, Equivalent chain-length. Fatty-acid analyses were performed using cells cultivated on the same medium and at the same temperature, but incubation time was different between CL-TF13 ${ }^{\mathrm{T}}$ (1 day) and the other strains (2 days).

\begin{tabular}{|c|c|c|c|c|c|}
\hline Fatty acid & 1 & 2 & 3 & 4 & 5 \\
\hline \multicolumn{6}{|l|}{ Straight-chain } \\
\hline $\mathrm{C}_{15: 0}$ & $2 \cdot 7$ & $8 \cdot 9$ & $4 \cdot 9$ & $3 \cdot 6$ & $2 \cdot 9$ \\
\hline $\mathrm{C}_{16: 0}$ & $0 \cdot 9$ & $0 \cdot 6$ & $0 \cdot 6$ & $0 \cdot 7$ & $0 \cdot 3$ \\
\hline $\mathrm{C}_{18: 0}$ & $0 \cdot 3$ & ND & ND & ND & $1 \cdot 4$ \\
\hline \multicolumn{6}{|l|}{ Branched } \\
\hline iso- $\mathrm{C}_{13: 0}$ & $1 \cdot 4$ & $0 \cdot 7$ & $0 \cdot 2$ & $0 \cdot 8$ & $1 \cdot 8$ \\
\hline iso- $\mathrm{C}_{14: 0}$ & $0 \cdot 7$ & $1 \cdot 7$ & $0 \cdot 9$ & $0 \cdot 8$ & $0 \cdot 8$ \\
\hline iso- $\mathrm{C}_{15: 0}$ & $18 \cdot 8$ & $17 \cdot 2$ & $9 \cdot 5$ & $13 \cdot 2$ & $16 \cdot 8$ \\
\hline iso- $\mathrm{C}_{15: 1}$ & $8 \cdot 2$ & $5 \cdot 3$ & $8 \cdot 2$ & $7 \cdot 1$ & $7 \cdot 6$ \\
\hline anteiso- $\mathrm{C}_{15: 0}$ & $1 \cdot 8$ & $0 \cdot 7$ & ND & $1 \cdot 1$ & $0 \cdot 8$ \\
\hline iso- $\mathrm{C}_{16: 0}$ & $2 \cdot 3$ & $3 \cdot 8$ & $1 \cdot 3$ & $1 \cdot 7$ & $0 \cdot 3$ \\
\hline iso- $\mathrm{C}_{16: 1}$ & $1 \cdot 3$ & $1 \cdot 7$ & $1 \cdot 7$ & $0 \cdot 8$ & ND \\
\hline iso- $\mathrm{C}_{17: 1} \omega 9 c$ & $1 \cdot 6$ & $0 \cdot 4$ & ND & $0 \cdot 6$ & ND \\
\hline \multicolumn{6}{|l|}{ Unsaturated } \\
\hline $\mathrm{C}_{15: 1} \omega 6 c$ & $1 \cdot 7$ & $4 \cdot 2$ & ND & $1 \cdot 6$ & $2 \cdot 2$ \\
\hline $\mathrm{C}_{17: 1} \omega 6 c$ & $0 \cdot 9$ & $1 \cdot 5$ & $1 \cdot 2$ & $0 \cdot 9$ & $0 \cdot 3$ \\
\hline$C_{18: 3} \omega 6 c(6,9,12)$ & $1 \cdot 5$ & - & - & - & - \\
\hline \multicolumn{6}{|l|}{ Hydroxylated } \\
\hline $\mathrm{C}_{15: 0} 2-\mathrm{OH}$ & $0 \cdot 7$ & $1 \cdot 2$ & $2 \cdot 5$ & $1 \cdot 1$ & $1 \cdot 1$ \\
\hline $\mathrm{C}_{15: 0} 3-\mathrm{OH}$ & ND & $3 \cdot 4$ & $8 \cdot 6$ & $2 \cdot 9$ & $3 \cdot 8$ \\
\hline iso- $\mathrm{C}_{15: 0} 3-\mathrm{OH}$ & $6 \cdot 6$ & $4 \cdot 6$ & $7 \cdot 8$ & $8 \cdot 0$ & $19 \cdot 8$ \\
\hline $\mathrm{C}_{16: 0} 3-\mathrm{OH}$ & $1 \cdot 6$ & $1 \cdot 3$ & $2 \cdot 1$ & $3 \cdot 2$ & $1 \cdot 5$ \\
\hline iso- $\mathrm{C}_{16: 0} 3-\mathrm{OH}$ & $6 \cdot 8$ & $12 \cdot 8$ & $12 \cdot 2$ & $9 \cdot 0$ & $5 \cdot 0$ \\
\hline $\mathrm{C}_{17: 0} 2-\mathrm{OH}$ & $0 \cdot 9$ & $0 \cdot 2$ & ND & $0 \cdot 8$ & ND \\
\hline $\mathrm{C}_{17: 0} 3-\mathrm{OH}$ & $0 \cdot 3$ & $0 \cdot 9$ & $2 \cdot 5$ & $0 \cdot 7$ & $0 \cdot 6$ \\
\hline iso- $\mathrm{C}_{17: 0} 3-\mathrm{OH}$ & $13 \cdot 6$ & $8 \cdot 4$ & $11 \cdot 7$ & $14 \cdot 9$ & $13 \cdot 7$ \\
\hline ECL 13.565 & $1 \cdot 3$ & - & - & - & - \\
\hline ECL 16.582 & $1 \cdot 3$ & $0 \cdot 7$ & $0 \cdot 6$ & $1 \cdot 0$ & $1 \cdot 0$ \\
\hline Summed feature $3^{*}$ & $19 \cdot 6$ & $18 \cdot 1$ & $22 \cdot 5$ & $24 \cdot 4$ & $17 \cdot 9$ \\
\hline Summed feature $4 \dagger$ & $1 \cdot 3$ & - & - & - & - \\
\hline
\end{tabular}

${ }^{*} \mathrm{C}_{16: 1} \omega 7 c /$ iso- $\mathrm{C}_{15: 0}$ 2-OH.

$\dagger$ Iso I-/anteiso B-C $17: 1$. 
the dominant fatty acids in CL-TF13 ${ }^{\mathrm{T}}$ were different from other Tenacibaculum species and three fatty acids, $\mathrm{C}_{18: 3} \omega 6 \mathrm{c}$ $(6,9,12)(1 \cdot 5 \%)$, summed feature 4 (iso I- and/or anteiso B$\left.\mathrm{C}_{17: 1}, 1 \cdot 3 \%\right)$ and an unknown fatty acid (ECL 13.565) $(1.3 \%)$, were uniquely found in minor quantities in CL$\mathrm{TF} 13^{\mathrm{T}}$ among Tenacibaculum species. Therefore, the fattyacid pattern of strain CL-TF $13^{\mathrm{T}}$ differed significantly from those of previously described Tenacibaculum species.

In conclusion, physiological features, fatty-acid profiles, phylogenetic analyses based on $16 \mathrm{~S}$ rRNA gene sequences and DNA-DNA relatedness suggest that strain CL-TF13 ${ }^{\mathrm{T}}$ represents a novel species of the genus Tenacibaculum, for which the name Tenacibaculum litoreum sp. nov. is proposed.

\section{Description of Tenacibaculum litoreum sp. nov.}

Tenacibaculum litoreum (li.to.re' um. L. neut. adj. litoreum of the shore).

Gram-negative, strictly aerobic and straight rods, approximately $0 \cdot 3-0 \cdot 5 \times 2-35 \mu \mathrm{m}$ in size. Cells are motile by means of gliding. On MA solid medium colonies are pale yellow, irregular with spreading edges and greenish glistening. After 5 days on MA at $30^{\circ} \mathrm{C}$ colonies are approximately $5-10 \mathrm{~mm}$ in diameter. Growth occurs within the temperature range of $5-40{ }^{\circ} \mathrm{C}$ (optimum $35-40^{\circ} \mathrm{C}$ ) and at $\mathrm{pH}$ values of $6-10$. Growth occurs in $\mathrm{NaCl}$ concentrations of 3-5\% (w/v) and in sea salt concentrations of $1-10 \%(\mathrm{w} / \mathrm{v})$. Positive for catalase, cytochrome oxidase, amylase, gelatinase, DNase and nitrate reductase and degradation of Tween 80. Major fatty acids are summed feature $3\left(\mathrm{C}_{16: 1} \omega 7 c\right.$ and/or iso- $\mathrm{C}_{15: 0} 2$ $\mathrm{OH}, 19 \cdot 6 \%)$, iso- $\mathrm{C}_{15: 0}(18 \cdot 8 \%)$ and iso- $\mathrm{C}_{17: 0} 3-\mathrm{OH}$ $(13 \cdot 6 \%)$. Also contains minor amounts of $\mathrm{C}_{18: 3} \omega 6 \mathrm{c}$ $(6,9,12)(1.5 \%)$ and summed feature 4 (iso I- and/or anteiso $\left.\mathrm{B}-\mathrm{C}_{17: 1}, 1.3 \%\right)$. According to API 20NE tests, activities for nitrate reductase and gelatinase are present, whereas activities for indole production, acid production from glucose, arginine dihydrolase and urease, hydrolysis of aesculin and $\beta$-galactosidase are absent. According to API ZYM tests, activities for alkaline phosphatase, esterase (C4 and C8), leucine arylamidase, valine arylamidase, cystine arylamidase, trypsin, $\alpha$-chymotrypsin, acid phosphatase and naphthol-AS-BI-phosphohydrolase are present, whereas activities for lipase (C14), $\alpha$-galactosidase, $\beta$-galactosidase, $\beta$-glucuronidase, $\alpha$-glucosidase, $\beta$-glucosidase, $N$-acetyl- $\beta$ glucosaminidase, $\alpha$-mannosidase and $\alpha$-fucosidase are absent. Growth occurs on Casamino acids, tryptone, yeast extract, peptone, L-arginine, L-ornithine, L-proline and Llysine. No growth occurs on acetate, benzoate, citrate, maleic acid, ethanol, glycerol, L-leucine, tartrate, pyruvic acid, succinate, sucrose, L-glutamate, D-ribose, DL-aspartate, $\mathrm{N}$-acetylglucosamine, L-arabinose, $\mathrm{D}$-xylose, $\mathrm{D}$-fructose, $\mathrm{D}$ glucose, D-mannose, D-trehalose, inulin, D-mannitol, Dsorbitol, D-salicin, D-raffinose, D-galactose, urea or lactose. The DNA G $+\mathrm{C}$ content is $30 \mathrm{~mol} \%$.

The type strain, CL-TF $13^{\mathrm{T}}\left(=\mathrm{KCCM} 42115^{\mathrm{T}}=\mathrm{JCM} 13039^{\mathrm{T}}\right)$, was isolated from a tidal flat sediment in Ganghwa, Korea.

\section{Acknowledgements}

We thank Mr Y. W. Lee (SEES, SNU) for the analysis of pigments and Dr J. H. Yoon (KRIBB) for providing genomic DNA of T. mesophilum MBIC $1140^{\mathrm{T}}$. This work was supported in part by the Special Grants Research Programme in Fisheries (MOMAF) to B. C. C. (20010021) and by the BK21 project of the Korean Government.

\section{References}

Altschul, S. F., Gish, W., Miller, W., Myers, E. W. \& Lipman, D. J. (1990). Basic local alignment search tool. J Mol Biol 215, 403-410.

Cole, J. R., Chai, B., Marsh, T. L. \& 8 other authors (2003). The Ribosomal Database Project (RDP-II): previewing a new autoaligner that allows regular updates and the new prokaryotic taxonomy. Nucleic Acids Res 31, 442-443.

Collins, M. D. (1985). Analysis of isoprenoid quinones. Methods Microbiol 18, 329-366.

Felsenstein, J. (1981). Evolutionary trees from DNA sequences: a maximum likelihood approach. J Mol Evol 17, 368-376.

Fitch, W. M. (1971). Toward defining the course of evolution: minimum change for a specific tree topology. Syst Zool 20, 406-416.

Frette, L., Jørgensen, N. O. G., Irming, H. \& Kroer, N. (2004). Tenacibaculum skagerrakense sp. nov., a marine bacterium isolated from the pelagic zone in Skagerrak, Denmark. Int J Syst Evol Microbiol 54, 519-524.

Hansen, G. H. \& Sørheim, R. (1991). Improved method for phenotypical characterization of marine bacteria. J Microbiol Methods 13, 231-241.

Hansen, G. H., Bergh, Ø., Michaelsen, J. \& Knappskog, D. (1992). Flexibacter ovolyticus sp. nov., a pathogen of eggs and larvae of Atlantic halibut, Hippoglossus hippoglossus L. Int J Syst Bacteriol 42, 451-458.

Jukes, T. H. \& Cantor, C. R. (1969). Evolution of protein molecules. In Mammalian Protein Metabolism, pp. 21-132. Edited by H. N. Munro. New York: Academic Press.

Kumar, S., Tamura, K. \& Nei, M. (2004). MEGA3: integrated software for molecular evolutionary genetics analysis and sequence alignment. Brief Bioinform 5, 150-163.

Lane, D. J. (1991). 16S/23S rRNA sequencing. In Nucleic Acid Techniques in Bacterial Systematics, pp. 115-175. Edited by E. Stackebrandt \& M. Goodfellow. Chichester: Wiley.

Lyman, J. \& Fleming, R. H. (1940). Composition of sea water. J Mar Res 3, 134-146.

Mandel, M. \& Marmur, J. (1968). Use of ultraviolet absorbance temperature profile for determining the guanine plus cytosine content of DNA. Methods Enzymol 12B, 195-206.

Minnikin, D. E., O'Donnell, A. G., Goodfellow, M., Alderson, G., Athalye, M., Schaal, K. \& Parlett, J. H. (1984). An integrated procedure for the extraction of bacterial isoprenoid quinones and polar lipids. J Microbiol Methods 2, 233-241.

Posada, D. \& Crandall, K. A. (1998). MODELTEST: testing the model of DNA substitution. Bioinformatics 14, 817-818.

Reichenbach, H. (1992). The order Cytophagales. In The Prokaryotes. A Handbook on the Biology of Bacteria: Ecophysiology, Isolation, Identification, Applications, 2nd edn, pp. 3631-3675. Edited by A. Balows, H. G. Trüper, M. Dworkin, W. Harder \& K. H. Schleifer. New York: Springer.

Saitou, N. \& Nei, M. (1987). The neighbor-joining method: a new method for reconstructing phylogenetic trees. Mol Biol Evol 4, 406-425.

Smibert, R. M. \& Krieg, N. R. (1994). Phenotypic characterization. In Methods for General and Molecular Bacteriology, pp. 607-654. Edited 
by P. Gerhardt, R. G. E. Murray, W. A. Wood \& N. R. Krieg. Washington, DC: American Society for Microbiology.

Stackebrandt, E. \& Goebel, B. M. (1994). Taxonomic note: a place for DNA-DNA reassociation and 16S rRNA sequence analysis in the present species definition in bacteriology. Int J Syst Bacteriol 44, 846-849.

Suzuki, M., Nakagawa, Y., Harayama, S. \& Yamamoto, S. (2001). Phylogenetic analysis and taxonomic study of marine Cytophagalike bacteria: proposal for Tenacibaculum gen. nov. with Tenacibaculum maritimum comb. nov. and Tenacibaculum ovolyticum comb. nov., and description of Tenacibaculum mesophilum sp. nov. and Tenacibaculum amylolyticum sp. nov. Int J Syst Evol Microbiol 51, 1639-1652.

Swofford, D. L. (1998). PAUP ${ }^{*}$ - Phylogenetic Analysis Using Parsimony, version 4. Sunderland, MA: Sinauer Associates.

Wakabayashi, H., Hikida, M. \& Masumura, K. (1986). Flexibacter maritimus sp. nov., a pathogen of marine fishes. Int J Syst Bacteriol 36, 396-398.

Yoon, J.-H., Kang, S.-J. \& Oh, T.-K. (2005). Tenacibaculum lutimaris sp. nov., isolated from a tidal flat in the Yellow Sea, Korea. Int J Syst Evol Microbiol 55, 793-798. 